\title{
Barriers and Fluids of the Eye and Brain
}




\title{
Barriers and Fluids of the Eye and Brain
}

\author{
Edited by \\ MALCOLM B. SEGAL \\ Sherrington School of Physiology \\ UMDS Guy's and St Thomas's Hospitals \\ London
}

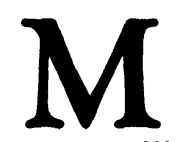

Palgrave Macmillan UK 
(C) The editor and contributors 1992

Originally published by Macmillan Academic and Professional Ltd in 1992

Softcover reprint of the hardcover 1st edition 1992 978-0-333-54977-3

All rights reserved. No reproduction, copy or transmission of this publication may be made without written permission.

No paragraph of this publication may be reproduced, copied or transmitted save with written permission or in accordance with the provisions of the Copyright, Designs and Patents Act 1988, or under the terms of any licence permitting limited copying issued by the Copyright Licensing Agency, 90 Tottenham Court Road, London WIP 9HE

Any person who does any unauthorized act in relation to this publication may be liable to criminal prosecution and civil claims for damages.

First published 1992

Filmset by Wearside Tradespools, Boldon, Tyne and Wear

ISBN 978-1-349-12308-7

ISBN 978-1-349-12306-3 (eBook)

DOI 10.1007/978-1-349-12306-3

A catalogue record for this book is available from the British Library 


\section{Contents}

The Contributors viii

Preface $\quad x i$

Some Autobiographical Notes Hugh Davson xv

Recollections of Hugh Davson William Oldendorf xxvii

1 Membrane transport in ocular epithelia J. A. Zadunaisky 1

2 Transport functions of the blood-ocular and blood-brain barriers, and the microenvironment of neuronal and nonneuronal tissues $\quad$ L. Z. Bito

3 Ocular pulsatile blood flow in healthy and diabetic eyes M. E. Langham

4 Physiology of the vitreous: a personal view D. M. Maurice

5 Role of carbonic anhydrase in aqueous humour and cerebrospinal fluid formation T. H. Maren

6 Pharmacological manipulation of cerebrospinal fluid secretion M. Pollay

7 Structural, ultrastructural and functional correlations among local capillary systems within the brain J. Fenstermacher, H. Nakata, A. Tajima, Mao-Hsiung Yen, V. Acuff and K. Gruber

8 Effects of phenylephrine and dopamine on locomotor activity and permeability of the blood-brain barrier of mice exposed to lead from birth $F . R$. Domer 
9 Mechanisms regulating peptide levels in the cerebrospinal fluid D. J. Begley and D. G. Chain

10 Blood-brain barrier permeability to peptides and proteins B. V. Zloković, J. G. McComb, M. B. Segal and H. Davson

11 Drainage of cerebrospinal fluid during development and in congenital hydrocephalus $H$. C. Jones

12 Development of the blood-brain barrier to macromolecules N.R. Saunders

13 Pathophysiology of communicating hydrocephalus: information provided by the new imaging modalities

A. E. James, Jr., C. H. Lorenz, J. A. McKanna, J. L. Creasy, C. L. Partain, E.-P. Strecker and W. Bradley, Jr.

14 Opening of the blood-brain barrier to D-mannitol induced by sensorimotor cortical lesions in the anaesthetized guineapig L. M. Rakić, B. V. Zloković, J. B. Mačkić, M. N. Lipovac, D. M. Mitrović, R. Veskov, Z. Redžić, M. B. Segal and H. Davson

15 Uptake of thiamine by the isolated perfused sheep choroid plexus D. M. Mitrović M. B. Segal, J. E. Preston, H. Davson and B. V. Zloković

16 Epileptogenic activity of metaphit-induced audiogenic seizure in small rodents $M$. N. Lipovac, V. Susić, B. V. Zloković, A. E. Jacobson, K. C. Rice, A. N. Popović, S. Popadić and M. E. A. Reith

17 Anticonvulsant effects of phencyclidine and PCP-like drugs on audiogenic seizures induced by metaphit in mice M. N. Lipovac, E. A. Debler, A. Lajtha, B. V. Zloković, A. E. Jacobson, K. C. Rice, A. N. Popović, S. Popadić and M. E. A. Reith

18 Cotransport of sodium, potassium and chloride in the isolated choroid plexus C. Johanson, J. Parmelee, D. Bairamian, S. Sweeney and M. Epstein 
19 Effect of congenital hydrocephalus on cortical structure in the H-Tx rat R. M. Bucknall, N. G. Harris and H. C. Jones

20 Role of the blood-brain barrier in immunopathogenesis of experimentally induced autoimmune demyelination

D. S. Skundrić, B. V. Zloković, M. B. Segal, L. J. Rakić and H. Davson

Index 


\section{The Contributors}

\section{J. Begley}

Biomedical Sciences Division

Kings College London

Strand

London WC2R 2LS

UK

\section{Z. Bito}

Ophthalmology Research

Columbia University

630 West 168th St

New York

NY 10032

USA

W. Bradley Jr.

Vanderbilt University

Nashville

TN

USA

D. G. Chain

The Weizmann Institute of Science

Rehovat 76100

Israel

\section{J. L. Creasy}

Vanderbilt University

Nashville

TN

USA

H. Davson

Sherrington School of Physiology
UMDS Guy's \& St Thomas's

Hospital

London SE1 7EH

UK

F. R. Domer

Dept of Pharmacology

Tulane University School of Medicine

New Orleans

LA

USA

J. Fenstermacher

Dept of Neurological Surgery

HSC T12-080

State University of New York

Stony Brook

NY 11794-8122

USA

\section{A. E. James}

Vanderbilt University

Nashville

TN

USA

\section{Johanson}

Dept of Clinical Neurosciences

Program in Neurosurgery

Brown University/Rhode Island

Hospital

Providence

RI 02903

USA 
H. C. Jones

Physiology Section

Division of Biomedical Sciences

King's College London

Campden Hill Rd

London W8 7AH

UK

\section{N. Lipovac}

Institute of Medical Physiology

Belgrade University

Faculty of Medicine

Belgrade

Yugoslavia

\section{H. Lorenz}

Vanderbilt University

Nashville

TN

USA

\section{J. A. McKanna}

Vanderbilt University

Nashville

TN

USA

\section{K. B. Mačkić}

Institute of Biochemistry

School of Medicine

Belgrade

Yugoslavia

\section{R. H. Maren}

University of Florida College of Medicine

Box J-267

JHMHC

Gainesville

FL 32607

USA
D. M. Maurice

Division of Ophthalmology

Stanford University School of

Medicine

San Francisco

CA

USA

\section{M. Mitrović}

Institute of Medical Physiology

Belgrade University

Faculty of Medicine

Belgrade

Yugoslavia

C. L. Partain

Vanderbilt University

Nashville

TN

USA

M. Pollay

Neurosurgical Section

University of Oklahoma Health Sciences Center

Oklahoma City

OK

USA

\section{J. E. Preston}

Sherrington School of Physiology

UMDS Guy's \& St Thomas's

Hospital

London SE1 7EH

UK

L. M. Rakić

Institute of Biochemistry

School of Medicine

Belgrade

Yugoslavia 
N. R. Saunders

Dept of Physiology and Pharmacology

University of Southampton

Bassett Crescent East

Southampton

Hants SO9 3TU

UK

\section{B. Segal}

Sherrington School of Physiology

UMDS Guy's \& St Thomas's

Hospital

London SE1 7EH

UK

E.-P. Strecker

Vanderbilt University

Nashville

TN

USA

\section{J. A. Zadunaisky}

Dept of Physiology and Biophysics

New York University Medical

Center

550 1st Avenue

New York

NY 10016

USA

B. V. Zloković

Division of Neurosurgery

Children's Hospital of Los Angeles 2025 2nd Avenue

Los Angeles

CA 90033

USA 


\section{Preface}

Over the past 40 years there has been remarkable progress in the understanding of the mechanisms by which the homoeostasis of the fluid microenvironment of the brain and eye is achieved. This period of time spans the research career of Hugh Davson, who, by his own scientific endeavours and those of his many students and colleagues, has played a major role in the understanding of these processes.

This volume reports the latest findings in the field of barriers and fluids of the eye and brain which were presented at a meeting held in London to mark the occasion of Hugh Davson's 80th birthday. Each paper was given by one of Hugh Davson's former students or research colleagues who have worked with him over the years and are now leading experts in the field.

The volume starts with four papers on the vegetative physiology of the eye. The first, by Jose Zadunaisky, reviews the potentials and ion transport mechanisms found at the various interfaces within the eye, and is followed by Lazlo Bito's discussion on the role of prostaglandins in the eye and cerebrospinal fluid (CSF). Both of these topics have been of key interest to Hugh over the years. Maurice Langham and David Maurice were among the first students to train with Hugh Davson and are pursuing distinguished careers in visual physiology. Maurice discusses the problem of the diabetic eye and David gives his own view on the function of the vitreous body.

Tom Maren, who is the 'father' of carbonic anhydrase and its inhibitors, makes a link between the eye and CSF, with a discussion of the role of this important enzyme in both fluids. Michael Pollay, a neurosurgeon who trained with Hugh in his early years and has keen research and clinical interest in CSF, discusses the factors which influence the secretion of this fluid.

Joseph Fenstermacher then enlivens the volume with his new combined method of studying the permeability of local capillary systems within the brain. His chapter is followed by one by Floyd Domer, who takes a pharmacological approach to the effects of lead intoxication on the blood-brain barrier and describes the difficulties of working with this common environmental pollutant.

There then follow two chapters on the permeability of macromolecules across the blood-brain barrier. The first of these chapters, by David Begley 
and Daniel Chain, reviews the mechanisms regulating peptide levels in the CSF, and is followed by a presentation by Berislav Zlokovic on the surprising new views on the permeability of the blood-brain barrier to macromolecules.

This chapter is followed by one describing the fascinating morphological studies of Hazel Jones on the development of CSF drainage pathways in both normal rats and those which have spontaneous hydrocephalus.

Norman Saunders then reviews the development of the blood-brain barrier and gives a glimpse of how the comparative physiology of the marsupial can give access to the early stages of the formation of the barrier in free-living neonates, which would be fetal in other mammals.

The final chapter is by Everett Jones (and his co-workers) who, as Professor of Radiology, presents his interesting latest findings on primate CSF drainage pathways. He then completes the major chapters in the volume by giving us a view of the future, with a review of the latest imaging techniques being developed for clinical diagnosis, which will be valuable tools for studying the basic physiology of the fluids of the brain in conscious man, using non-invasive techniques.

At the end of the volume there are a number of short communications from Hugh's young colleagues from Yugoslavia and London who attended the meeting. Hugh has always enjoyed encouraging the young scientist, so no volume dedicated to him would be complete without these abstracts, which hold the promise for the future.

Although I was responsible for the initial idea of this meeting and for much of the local organization, it would not have been possible without the tremendous help and advice freely given by Professor Michael Bradbury at King's College. Mike preceded me in Hugh's laboratory, and it seemed at the time that Mike had already thought of every idea I had for a new project and had performed the experiment during the previous three years!

Mike and I spent a considerable period of time attempting to raise adequate funding, but it is surprising that drug companies, many of which have benefited from Hugh's work, are reluctant to fund basic science, yet will donate large sums for clinical meetings. However, some companies were most helpful and I must thank the following for their generosity: Beechams Research; Imperial Chemical Industries; Smith Kline \& French and Pfizer Central Research. We also approached those publishers who have directly benefited from Hugh's writing, but apart from Academic Press, who were most kind, we had no success. In contrast, the Wellcome Trust, without which medical research in the United Kingdom would have foundered, were most generous and we must thank them for making this meeting possible.

We had already invited all of Hugh's closest colleagues who are still busy with research all over the world; they came in spite of our inability to pay their travel costs. The shortfall in funding made us particularly sad, since 
Mike and I have been so well looked after in our travels abroad, especially in the USA. We were particularly sorry that this lack of funding meant that Emilio Levin (Argentina) could not be with us.

I began to write some biographical notes on Hugh's career but in the end, after my repeated questions, Hugh decided it would be easier for him to do this himself. This amusing essay follows my introduction.

Hugh has had a considerable influence on research, both through scientific papers and in his books. Those of us who have been privileged to work with him have also enjoyed his friendship and the ability of his keen mind to challenge our hypotheses and fire us with enthusiasm for the next problem.

As you will read, Hugh has often clashed with the more pompous members of the scientific establishment, which for most of us would have spelt the end of our career. Hugh, however, has managed to defeat their machinations, to follow a career dedicated to excellence in research. One of his most endearing characteristics is the help he has always been willing to give to young scientists and to anyone who has come to his laboratory for advice. He has wonderful patience, and will always listen and give his time freely to help others who seek assistance, carefully breaking down the problem in a concise and logical manner. It is a reflection of this ability that the meeting was attended by a large number of young scientists, who came not only for the science, but also to enjoy his lively conversation and company. Hugh has the ability to communicate with all generations and he treats small children as little adults, so that at gatherings of friends and family all the young are found having earnest conversations with Hugh and ignoring the rest of the party.

Communication and language has been his particular forte and he is fluent in French, German and the Romance languages. In recent years, during our co-operation with Yugoslavia, he has learned Serbian for fun, so that when he was elected a member of the Serbian Academy of Sciences, he gave his inaugural address in this, the most difficult of tongues.

I started assisting Hugh with the publication of his many books in 1968 while writing up my PhD. Hugh's first book was Permeability of Natural Membranes, published in 1940 with Danielli. This book has been a major influence on permeability studies and is still available today as a reprint. Hugh no longer receives any royalties, as the rights were sold by the publisher to America many years ago. His second book, on the Physiology of the Eye, has run through six editions, the latest being published in 1990. Hugh has written a Textbook of General Physiology, which ran to four editions, and I well remember helping with the proof reading. Keasley Welch said at the time that Hugh was writing faster than we could read the proof! Hugh's other great interest in the CSF and blood-brain barrier has led to three books on this topic, the latest being Physiology and Patho- 
physiology of the CSF, and a new volume, a more simple approach to the blood-brain barrier, is in preparation at present. Hugh has also written an Introduction to Physiology in five volumes, and edited the multivolume tome The Eye. At University College London with Grace Eggleton, he also produced several editions of Starling's Textbook of Physiology, which sadly is no longer in print.

I cannot finish without a mention of Hugh's technician, the long-serving Charlie Purvis, who came with him from the Institute of Ophthalmology to University College and built an amazing range of infusion pumps and pressure transducers, without which much of the work could not have been done. The infusion pumps worked at rates down to less than $1 \mu \mathrm{l} / \mathrm{min}$ and were amazingly stable. The equivalent at today’s prices costs $£ 3500$ ! The transducers were based on a bronze diaphragm and, being mechanical, used a light lever to record tiny pressures of a few $\mathrm{cm}$ of water; with the fine taps he also constructed, they made work in the laboratory a pleasure.

Hugh is still as busy as ever, and as well as writing we are planning some new experiments on an old problem: if successful, we hope to unravel the source of brain extracellular fluid.

We are now discussing plans for the meeting of Hugh's 90th and 100th birthdays, and are fortunate that, although many of us will have 'shuffled off this mortal coil', Hugh's young friends will be there! 


\title{
Some Autobiographical Notes
}

\author{
Hugh Davson
}

I was educated at University College School, my father having decided that a change from St. Paul's School, which my elder brothers attended, might be beneficial. I had stayed at my preparatory school a year longer than usual, so that I assumed that I could get along at University College School with no particular effort, as had been the case in my last year at preparatory school. The change from sympathetic to sour and sarcastic teachers, who took pleasure in making fun of pupils, who had no opportunity to answer back, was too sudden and my response was to do no work. My father assumed that I was good for nothing, and so, when I had taken my matriculation, without knowing the result but presuming that I had failed, arranged for me to be taken on by one of his patients, the managing director of a firm operating on the Baltic Exchange. The job was equivalent to an articled clerkship, in the sense that one was unpaid for five years and then became a member of the Exchange, and the going was good for the rest of one's life. The trouble was that there was nothing to learn in those five years that a person of ordinary intelligence could not have picked up in six months' study; after two years, fortunately, I was sacked, presumably for not showing interest! Having passed my matriculation at first taking, a fairly unusual feat then, I was entitled to enter London University, so, as my father agreed to pay the fees, I filled in the necessary form and signed on for chemistry rather than medicine-not that I knew much about chemistry, but I had seen the dog's life a general practitioner led in those days. Thus, I started university life two years after I could have done if I had gone straight from school. In my first year I had to study hard, as I knew little compared with boys who had stayed on at school and failed their Higher School Examinations. I passed these intermediates at a high level and in the second and third years I was up against the cream of scholarship — boys who had passed their Highers and so gained a free place at university. In the final year the results of the examinations taken preliminary to the degree examinations made interesting reading: top were always the triumvirate, usually in alphabetical order, of Brightman, Danielli and Davson. The first two were scholarship types whose brains had survived the ordeal of the scholarship grind. Neither Danielli nor myself could ever beat Brightman, because he had a memory that was 
completely photographic, and also the intelligence to profit from it. Danielli had the advantage over me of his more thorough training at his secondary school, so that higher mathematics was natural to him, whereas I had had to pick it up as best I could. The results of the BSc examination came out in the predictable order, the triumvirate having firsts.

If times had been prosperous in England at that time, I think the course of my career would have been different: I would have been snapped up by ICI. However, the year of my degree was 1931, when unemployment had reached the three million figure and the Government was retrenching, cutting salaries and even persuading the holders of $5 \%$ War Loan to take $3 \frac{1}{2} \%$ voluntarily. Thus, I was 'driven' into an academic research career, in the sense that I had to continue postgraduate work.

I had been fascinated by the science of statistical mechanics, a mathematical approach to physical and chemical problems that was full of possibilities. The Professor of Chemistry at the time was C. K. Ingold, whose lectures on the theory of chemical reactions fascinated me; I felt that if $\mathrm{I}$ worked with him, I would be able to realize my intentions of following the statistical mechanical approach. I told him my views and he took me on, but, instead of taking my interest to heart and advising me to study forms of higher mathematics, he pulled out a box file, took out some papers and said: 'This is your project: get on with it.'

The project was the hydrogenation of a conjugate double bond compound which first had to be synthesized; a previous research student had obviously failed and I was to take it on. The synthesis of the compound I was supposed to hydrogenate was very difficult and nobody thought of giving me any help beyond telling me that I should polish my bench more carefully; thus, by the end of this first year of research, I was told that I could not be put forward for a research grant. With no prospect of further financial help from my father, who was on the point of retiring, this created quite a problem: I had married secretly and my wife, Marjorie, was showing signs of reproduction. Having been interested, along with Danielli, in the problem of permeability of cell membranes, having listened to a series of lectures by J. C. Drummond, then Professor of Biochemistry, in which he had described some interesting effects of calcium on the permeability of the estuarine worm Gunda ulvae, and having had informal chats with him on several occasions, I went to him, explained my situation and asked him whether he would apply on my behalf for the research grant. I proposed to work on permeability, a subject on which Drummond, a vitamin chemist, had had no experience. As a testimonial to a man I revered and loved more than anyone else in the world, I can say that he took me on and gave me a free hand. I obtained the necessary grant, reduced by government economy from $£ 150$ to $£ 120$, and I can remember the raptures with which the first quarterly instalment, of $£ 30$, was received. A bank account was immediately opened and a cheque for five shillings was sent proudly to a brother, who had probably lent that amount. 
I was then left to my own devices. Having dipped into the literature, I had decided that the permeability of red cells to potassium and sodium was interesting, so the problem of chemically determining these ions in organic matter occupied me for a very considerable time.

In spite of considerable difficulties in the chemical analysis of these ions I produced a paper which was published in the Biochemical Journal (1); it had been reviewed by Rudolf Hober, the leading German general physiologist, a recent refugee from Hitlerism. Looking back on it, I realize the appalling mistakes I had made in my experimental approach, although, of course, the actual results were impeccable. The mistakes were, I am sure, due to a lack of supervision, but then there were no qualified general physiologists about.

However, to get on with my story, my grant was drawing to a close and I was faced with the prospect of a starving wife and baby if I did not get another grant. Professor Drummond called me into his office one day and said that he had a job for me with Glaxo, at, I think, $£ 300$ a year. The research was naturally to be on matters of industrial importance but I was to have some chance of doing research on my own; he said, in all kindness, that I owed it to my wife to take the job. Looking back, I am amazed that I did not do so; $£ 300$ a year was six pounds a week, compared with the two pounds ten shillings that we were scraping along on. However, I remember I thanked him and said that my wife would not forgive herself if I abandoned a pure research career, although I am sure I never mentioned the matter to her at all! Interestingly, as a parenthesis, the man who did take the job was Magnus Pyke, who was doing a $\mathrm{PhD}$ on vitamins and was obviously more suited to it than myself.

The next development was that a successful ophthalmologist, Stewart Duke-Elder, who prided himself on his contributions to the physiology and biochemistry of the eye, having operated on Prime Minister Ramsay Macdonald for glaucoma, was given a knighthood and then needed someone to continue his researches. I was the someone and was given a grant of $£ 250$ a year, which transformed my life from one of complete penury to one in which I could afford to buy a few ounces of tobacco a week; beer, I recollect, was still out of the question.

The immediate problem was whether the cause of primary chronic glaucoma was a swelling of the vitreous body, a theory proposed by Duke-Elder. I naturally assumed that he was right and did my best to prove it, but it became more and more obvious that this was an incorrect hypothesis. I finally managed to explode the idea by obtaining an eye in absolute glaucoma and taking the vitreous out. My argument was that if it was causing a pressure of perhaps $50 \mathrm{mmHg}$ in the eye, it must have a swelling pressure to correspond; in fact its swelling pressure, which I was able to measure by a special device, was less than a few millimetres of water. With my aid, therefore, Duke-Elder was able to show that he had been wrong, in a paper entitled 'The swelling pressure of normal and 
glaucomatous vitreous bodies' (2). This is an interesting paper: I submitted it to the Biochemical Journal but it was rejected on grounds that showed the referee did not understand the problem. By objecting to this, I came into conflict for the first time with the Establishment, this time in biochemistry. The editor was C. R. Harington, and I can remember my Professor, Drummond, calling me in to say that I must make my peace with him because I had said to one of his underlings, whom I had met in a pub, that I thought the criticisms of my paper were stupid! However, being young and independent, peace was not made and I paid for this indiscretion subsequently.

While working on the eye, I also continued my studies on the permeability of the erythrocyte. Danielli had, meanwhile, been in the USA on a Commonwealth Fellowship and had carried out work on the plasma membrane, following up an idea we had had together at University College when trying to explain the effects of calcium on the worm Gunda ulvae; we thought that it could be the effect of the divalent ion on the surface film of lipid that would bind the lipid molecules closer together. Danielli wrote the paper that was to have so much influence on thought so far as the cell membrane was concerned (3). In this context, I must say that Jim Danielli was precocious to an uncommon degree; usually the precocious schoolboy gets to a university but after that fades out. Danielli not only got to a university but also obtained a good first and then became a first-class research worker; there was no feeling his way, so that in all my association with him, which lasted from, say, 1933 to 1937, when he went to Cambridge, he was the 'superior spirit'. Together we wrote a number of papers on red cell permeability and laid the foundation for the paucimolar theory of the membrane.

In 1935 I asked Professor Drummond whether I could get a fellowship to spend a year in America; he thought it was a good idea and approached the Rockefeller Foundation, who awarded me a fellowship in 1936. I suppose I had made a small reputation for myself in the field of permeability, and the leading general physiologist, M. H. Jacobs, took me on to do a year with him. Although I did not get much help from him, I did learn that you must repeat your results thoroughly before committing yourself to print. I was actually disappointed by him, because I was interested in the effects of narcotics on permeability; Danielli and I had thought that these should decrease permeability by virtue of their action on the surface film membrane-a concept that dominated our thinking at the time. Jacobs had found that they had, if anything, the opposite effect, but he was working with ox red cells. By chance I chose rabbit red cells and found a profound decrease in permeability to glycerol by ethyl alcohol; however, I was discouraged from publishing these controversial results. I had in fact discovered an important feature of permeability, since it turned out that the facilitated transport type of permeability, of which Danielli and I were 
just beginning to become aware, was liable to effects of narcotics, whereas the plain, non-facilitated type of transport was not. The non-publication of these data actually retarded progress in the understanding of transport processes.

During my stay in the USA I had applied for a Beit Fellowship, a coveted award that enabled the holder to carry out research for three years with prospects of a senior fellowship for another three years. On returning to London I agreed to continue work on the eye but my main interest was now the cell membrane. The Fellowship began in 1937 and by 1938 Professor Drummond thought that I should find a teaching job, as ultimately I must take one if I was to become a professor, the only possibility of advancement in those days. I successfully applied for the position of Associate Professor at Dalhousie University, Canada. Prior to my departure for Canada, I had Peter Quilliam to assist me; he was a good practical physiologist and acquired the technique of perfusing the isolated cat's head with the Starling heart-lung preparation. Using this perfusion system, I was able to modify the concentration of potassium in the blood and measure the blood-aqueous barrier; this, I suppose, was the first quantitative study in which I developed the two-compartment kinetics that forms the basis of most subsequent work on the ocular and cerebrospinal fluids (4).

I had spent the two previous summers at Cold Spring Harbor, the Director of which, Eric Ponder, was an authority on the red blood cell. He encouraged me to do research with him (5). I went to Canada from New York by boat and then by rail to Halifax; on the train I learnt that Britain was at war.

My chief at Dalhousie was Professor Weld, who was mainly interested in teaching, but that created an ideal situation for me, as all the money available for research was at my disposal. I got Professor Weld to help in a study of the effects of aphakia on the composition of the aqueous humour (6). Meanwhile I learnt a great deal of physiology, as there were only the two of us to do all the teaching of medical students. All this time I was doing my best research work; my day usually consisted of arriving at about 8.30 a.m., giving a lecture from 9 until 10, and then plunging straight into the laboratory. I was not much worried during the period of the "phoney war', but when the Germans looked like winning, I wrote to my Professor (Lovatt-Evans) in London, asking him to help me to get back to do wartime research; in 1942 I and my family embarked on the Sarpedon, a former P \& O liner, in convoy for Liverpool. We arrived in Liverpool without any serious incident and began life in England.

I was sent to work at the Chemical Defence Establishment at Porton Down in Wiltshire. Here I found that there was a new gas, nitrogen mustard, that attacked the eyes, so I devised various experimental set-ups with rabbits to measure the effects on the aqueous humour. To this end I 
brought Peter Quilliam down from London and together we did some interesting work on the effects of nitrogen mustard which has a permanent place in the literature of the aqueous humour (7). After a year or so of Porton, as the threat of gas attacks receded, I felt that I was doing no useful service and I eventually moved to London with the Army Operational Research Group.

AORG was created by the war and used everybody's talent to the best. Because of my experience on the eye, I rather ambitiously took on visual problems and was involved at once with infra-red illumination. You had an infra-red searchlight which illuminated the scene only to those who had the necessary infra-red receivers. It was excellent fun: I learnt to drive heavy army lorries, Sherman tanks, armoured cars, and even bulldozers, all with the aid of infra-red illumination. I also managed to lose a searchlight, and, since I signed for it, I am always slightly worried that one day the MoD will send me a bill!

At the end of the war I was faced with a dilemma: I had been given leave of absence from my job as Professor in Canada, but the university had appointed a temporary occupant of the position and wanted to know whether I intended to return. If I had had any sense, I would have gone back for a short period, because I feel sure now that I would have been offered a number of academic posts. As it was, the thought of Canada was too much for me, so I gave in my resignation and was on my own.

Over the past few years I had been in contact with Duke-Elder and we had discussed plans for an Institute of Ophthalmology in which there would be a department of research, which I would head. We persuaded the Medical Research Council to give us a grant to start some research on the eye at University College. With Duke-Elder I built up a team of some four or five young people who subsequently obtained their $\mathrm{PhD}$ degrees on projects initiated by myself. The group consisted of David Maurice, Maurie Langham, A. M. Woodin, E. J. Ross and N. Ambache (8).

When the building for the Institute of Ophthalmology had been converted for its purposes, I moved my team in and work proceeded with tolerable harmony for perhaps a year. However, before long there was a clash of personality between Duke-Elder and me, so I went to the MRC. We all have crises in our lives and this was the most appalling crisis in mine: once again I was flying in the face of the Establishment. Fortunately, Professor Gaddum of University College Pharmacology Department was on the Council, and when the matter was brought up, he was able to state, in no uncertain terms, that I was the guiding light in the whole research unit and that it was scandalous that I should be allowed to leave. However, prejudice in favour of the Establishment prevailed, so instead of my being put in absolute control of the unit (which, I must say, I had not asked for-merely to be released from the Institute), I was allowed to set up myself with one technician, my instrument maker, Mr Purvis, who said he 
would leave the Institute if he were not allowed to work with me, and a secretary. Thus, I began research life again at a time when I and one or two associates should have been engaged in either developing my theories of permeability or developing theories as to the nature of the relations between blood and the tissues of the eye-namely, aqueous humour, cornea and lens $(9,10)$. These areas have been studied by my younger colleagues with no subsequent help from me, because of my withdrawal, and, of course, no competition, since I felt myself bound to abstain from research in those fields in which I had given these younger colleagues my advice.

It was because of this that I turned to the study of the cerebrospinal fluid. I began studies of the blood-CSF barrier in, I suppose, about 1953, having first completed a study on the blood-aqueous in collaboration with my personal technician, Parnel Matchett, who moved with me, along with $\mathrm{Mr}$ Purvis from the Institute of Ophthalmology, in, I think, 1951. After publishing this study with Matchett (11), I studied the blood-aqueous and blood-CSF barriers simultaneously in the rabbit, using partly chemical and partly isotopic techniques, ${ }^{24} \mathrm{Na}$ having become available on a weekly basis. While doing this initial study, which lasted some two years, I decided that I must get to know the literature of the CSF and blood-brain barrier and, as the easiest way to do this, wrote a book. This was Physiology of the Ocular and Cerebrospinal Fluids and it came out in 1956, at about the same time as the 1955 paper on CSF and eye fluids (12). (Previously I had published Physiology of the Eye in 1949 and Textbook of General Physiology in 1951.)

In 1953 I was invited to spend a few months in Rio de Janeiro with Professor Chagas, who had built up a biophysics laboratory in which the electric organ was the main subject of study; I remember Richard Keynes had preceded me. To pass the time I measured the concentration of $\mathrm{K}^{+}$in intra- and extracellular fluids and showed that they were consistent with a resting potential of some $50 \mathrm{mV}(13)$.

About this time, Cecil Luck spent a year with me at University College. $\mathrm{He}$ had been in Africa and had arrived in England looking for a job; he was in the Department of Physiology, working with young Michael de Burgh Daly, and G. L. Brown, I think, suggested that I take him on. At any rate, I asked him to join me on a comparative study of aqueous humour and CSF in mammals; we were analysing their fluids for chloride and bicarbonate (14). He handled animals well, including monkeys, and we did some very good work. As a result of this, when the chair at McKerrerie in Uganda became vacant, he was able to convince the selectors that he could do some good work on comparative physiology of mammals and obtained the chair.

The first American to spend a year with me was Gene Spaziani, from Los Angeles. He had been trained in endocrinology but his chief thought that he should learn something about permeability. He performed experiments 
on both the eye and the blood-brain barrier (BBB) (15) - in particular, the work with brain slices that was the first 'brick' thrown at the anatomists, led by my colleague J. Z. Young at University College, who were claiming that the BBB was a fiction.

Later, in 1961, I spent a summer at Wood's Hole doing a little research on the eye fluids of fish; Cynthia Grant and I published a small note in the Biological Bulletin. While there, I received a telephone call from Keasley Welch, Professor of Neurosurgery at Denver, who had seen a notice in Science to the effect that I was in the country; I spent a few days in Colorado with him, giving seminars in sufficient number to defray the costs of myself and my wife. This formed a basis of a lasting friendship between us, a friendship shared by many of my younger colleagues, so when Keasley moved to Boston Children's Hospital, this lovely city became, and still is, the first stop for many of us on our various tours.

After Spaziani, I think the next American was Chuck Kleeman, also rather more of an endocrinologist than a general physiologist. He made an excellent study on the kinetics of the barrier to urea (16). My next visitor was a young colleague of Keasley Welch's, Mike Pollay. He developed the ventriculocisternal perfusion set-up in the rabbit (17) and subsequently was given the first chair in neurosurgery at Albuquerque. When Pollay left me, the MRC, who had previously refused stubbornly to provide any help in the way of qualified research workers, allowed me to take on Michael Bradbury, who had read my book on the fluids, and asked the new professor at Oxford, G. L. Brown, who had gone there from University College, to arrange this.

In 1963 I was approached, cap in hand, by a Louisville ophthalmologist, Dwight Townes, who wanted to found an Institute of Ophthalmology in Louisville and asked whether I would be the director of research and visiting distinguished professor. I agreed to this, as I could now leave my London laboratory in charge of Bradbury. Meanwhile, Laszlo Bito had written, asking whether he could do a post-doctoral couple of years with me. I told him that I was going to Louisville and that I presumed he would not want to go there. However, he said he would and he arrived a few weeks before I did. I soon discovered that all that was wanted of me was my signature at the bottom of application forms for grants. Thanks to Bito's moral support, I refrained from throwing in the sponge and we spent a profitable year working on the eye and CSF (18); it was there that we did the first 'microdialysis' experiment in an attempt to measure the true extracellular concentration of potassium in the brain, my idea being that it would be equal to that in the CSF. Our membrane sac was large, however, and had to be implanted in the forebrain of a dog and allowed to stay there for some weeks before we could venture in to get the fluid. Within the last few years the technique has been improved out of all recognition, and we are actually setting up the system at St. Thomas's. 
While at Louisville I took part in a symposium in Buenos Aires. Here I met Zadunaisky, whom I persuaded to take on my job at Louisville after I left in 1964; I also met again Emanuel Levin, who had worked for a few months with me and had established the technique of ventriculocisternal perfusion in the cat.

After my return to London, Bito came to do a second year and, together with Bradbury, we spent a very exciting period working mainly on the active transport of iodide and bromide across the blood-brain barriers (19). When Bito left, Bradbury went to work in Los Angeles with Kleeman, where he stayed some three years.

In 1967 Bill Oldendorf spent a year with me; his interest had been confined to X-ray studies of the CSF system in humans, so working on rabbits was new to him (20). When he went back to Los Angeles, he devised the now famous BUI technique; I remember his writing to me outlining it and asking whether I approved, and Bradbury and I both encouraged him to go on. In 1971 he sent me a reprint of his first paper on the technique and wrote in the cover: 'See what a year in Davson's laboratory does for you.'

When he left, I was approached by Malcolm Segal, who was taking his finals in physiology, and he spent some three years doing his $\mathrm{PhD}$ with me. We did some very good work together, made possible by the unfailing skill of my instrument maker, Mr Purvis (21). We were the first to measure the resistance to drainage of the CSF, a technique that was followed up by the Americans (22).

In about 1970, Dr Joan Abbot wrote to me from the USA, telling me that she had got a 'rehabilitation grant' permitting her and her husband to return to England, having regretted, I presume, falling down the 'brain drain'. At the same time, the MRC suggested that a member of the Carshalton Unit, Dr Ian Glen, might benefit by a year's work in my laboratory. Both Joan Abbott and Ian Glen spent a year with me, after which Joan obtained a position at King's College and Ian Glen one in Edinburgh (23). During this period, Jack Stulc from Czechoslovakia also joined the laboratory, so a most enjoyable and productive time was had by all.

When Segal left to go to St. Thomas's, where Bradbury had taken a job, Keasley Welch decided to spend a year with me; he had taught himself a lot of mathematics and so was able to analyse the blood-CSF, blood-nerve and blood-brain barriers in a manner that I, with my more limited knowledge of mathematics, would not have attempted (24).

In about 1972 Dr Floyd Domer, a pharmacologist at Tulane University, New Orleans, came to do a year's sabbatical in the laboratory (25). Floyd was unusual in that he could drink as much beer as an Englishman!

In South America David Yudelivich was having trouble with the change of government in Chile and I was able to persuade the MRC to support him 
for a year in the laboratory before he obtained the chair in physiology at Queen Elizabeth College.

I continued working at University College with my technician, Gillian Hollingworth (26), until I was due to retire at about age 66. Meanwhile the Fogarty Foundation had invited me to take a scholarship for a year after retiring, so I went to work at the NIH for a year. During this year I had all the money I wanted to organize a symposium on the Ocular and Cerebrospinal Fluids, and took pleasure in inviting all my colleagues, including two technicians, to come to it with all their expenses paid. It gave me great pleasure to see them all, especially Mr Evans, who had been chief technician at University College since I began research there in about 1933. He had seen one after another of us going to the USA but never dreamed of being invited there himself, and I think he enjoyed himself very much and looked the most distinguished of all those present!

After my year at Bethesda, during which I spent as much time as possible visiting my former colleagues in different parts of the USA, I returned to London and obtained a three-year grant from the MRC. I had intended to work at University College but changed my mind and moved to King's College in Mike Bradbury's laboratory. There my first visitor was Mike Michaelson from Cincinnati, to study dipeptides (27); next came Mike Carey, a New Orleans neurosurgeon, who studied the effects of insulin hypoglycaemia on the barriers (28); and finally, Joe Fenstermacher, who spent a year studying amino acid transport out of CSF (29).

At the expiry of my grant, I was shocked at the impudence of the MRC, who refused me another one; however, the Wellcome Trust came to my aid and I continued for several more years, roping in to my work David Begley. We employed Danny Chain, the son of the penicillin Chain, as our technician (30); he has now taken a PhD in Israel and is working in the USA. While at King's I had made the acquaintance of Berislav Zloković, who had been doing a stint with Yudelivich at Queen Elizabeth College. Berislav collaborated with me and Malcolm Segal (31) and has now taken up a job with Gordon McComb in Los Angeles. Gordon spent the year 1974-1975 in my laboratory; an excellent neurosurgeon, he was able to cannulate the sagittal sinus and torcula of the rabbit (32). I think it was while Gordon was working with me that Everette James came over and did some work on drainage of CSF. He was fundamentally a radiologist, who had kindly invited me to Vanderbilt when I was at Bethesda.

Of recent years I have been busy with writing a further edition of Physiology and Pathophysiology of CSF with Keasley Welch and Malcolm Segal and the fifth edition of Physiology of the Eye. Malcolm Segal arranged for me to be a visiting Professor at UMDS St. Thomas's Hospital, and I have an office in the Sherrington School of Physiology. Here I have enjoyed the many visits of our young Yugoslav colleagues, students of Berislav Zloković, who visit London to work in Segal's laboratory sup- 
ported by the British Council and the kindness of the Wellcome Trust. I had an amusing time disproving, with Jane Preston, Segal's PhD student, my dear friend Tom Maren's finding that aluminium completely inhibited CSF secretion; we found that the observed inhibition was in fact a $\mathrm{pH}$ colour artefact and that CSF secretion is only slightly reduced by this ion (33). My current line of research with Sarah Williams, another of Segal's students, involves laying the 'spectre of Stern and Gautier's hypothesis', which will appear in press in the near future.

\section{REFERENCES}

1. Davson, H. (1934). Studies on the permeability of the erythrocytes. Biochem. J., 28, 676-683

2. Duke-Elder, S., Davson, H. and Benham, G. H. (1936). The swelling pressure of normal and glaucomatous vitreous bodies. Br. J. Ophthalmol., 20, 320-527

3. Danielli, J. F. and Davson, H. (1935). A contribution to the theory of thin films. J. Cell Comp. Physiol., 5, 495-508

4. Davson, H. and Quilliam, J. P. (1940). The permeability of the blood-aqueous humour barrier to $\mathrm{K}^{+}, \mathrm{Na}^{+}$and $\mathrm{Cl}^{-}$in the surviving eye. J. Physiol., 98, 141-154

5. Davson, H. and Ponder, E. (1938). The permeability of 'ghosts' to cations. Biochem. J., 32, 736-762

6. Davson, H. and Weld, C. B. (1941). Studies on aqueous humour. Am. J. Physiol., 134, 1-7

7. Davson, H. and Quilliam, J. P. (1947). The effects of nitrogen mustard on the permeability of the blood-aqueous humour barrier to Evans Blue. Br. J. Ophthalmol., 31, 717-721

8. Davson, H., Duke-Elder, W. S., Maurice, D. M., Ross, E. J. and Woodin, A. M. (1949). The penetration of some electrolytes and non-electrolytes into the aqueous humour and vitreous body of the cat. J. Physiol., 108, 203-217

9. Langham, M. and Davson, H. (1949). Studies on the lens. Biochem. J., 44, 467-470

10. Davson, H. (1949). The aqueous humour and the blood-aqueous barrier. Ophthalmic Literature, 3, 254-268

11. Davson, H. and Matchett, P. A. (1951). The control of intraocular pressure in the rabbit. J. Physiol., 113, 387-397

12. Davson, H. (1955). A comparative study of the aqueous humour and cerebrospinal fluid in the rabbit. J. Physiol., 129, 111-133

13. Davson, H. and Lage, H. V. (1933). The extracellular space and internal K concentration of the electric organ of Electrophorus electricus. Acad. Brazil. Ciencas, 25, 303-307

14. Davson, H. and Luck, C. P. (1956). A comparative study of the total $\mathrm{CO}_{2}$ in ocular fluids, CSF and plasma of some mammalian species. J. Physiol., 132, 454-464

15. Davson, H. and Spaziani, E. (1959). The blood-brain barrier and the extracellular space and the brain. J. Physiol., 149, 135-143

16. Kleeman, C. R., Davson, H. and Levin, E. (1962). Urea transport in the central nervous system. Am. J. Physiol., 203, 739-747

17. Pollay, M. and Davson, H. (1963). The passage of certain substances out of the CSF. Brain, 86, 137-150

18. Bito, L. Z., Davson, H., Levin, E., Murray, M. and Snider, N. (1965). The relationship between the concentrations of amino acids in ocular fluid and plasma of dogs. Exp. Eye Res., 4, 374-380

19. Bito, L. Z., Bradley, M. W. B. and Davson, H. (1966). Factors affecting the distribution of iodide and bromide in the CNS. J. Physiol., 185, 323-354 
20. Oldendorf, W. M. and Davson, H. (1967). Brain extracellular space and the sink action of CSF. Arch. Neurol., 17, 196-205

21. Davson, H. and Segal, M. B. (1970). The effects of some inhibitors and accelerators of sodium transport on the turnover of ${ }^{24} \mathrm{Na}$ in the CSF. J. Physiol., 209, 131-153

22. Davson, H., Hollingworth, G. and Segal, M. B. (1970). The mechanism of drainage of the CSF. Brain, 93, 665-678

23. Abbot, N. J., Davson, H., Glen, I. and Grant, N. (1971). Chloride transport and potential across the blood-CSF barrier. Brain Res., 29, 185-193

24. Davson, H. and Welch, K. (1971). The permeation of several materials into the fluids of the rabbit brain. J. Physiol., 218, 337-351

25. Domer, F. R., Davson, H. and Hollingworth, G. R. (1973). Subarachnoid versus ventricular perfusion in the rabbit brain. Brain Res., 38, 81-94

26. Hollingworth, J. G. and Davson, H. (1973). Transport of sulphate in the rabbit's brain. J. Neurobiol., 4, 389-396

27. Begley, D. J., Davson, H. and Michaelson, M. A. (1980). Clearance of the dipeptide glycyl-1-glycine from rabbit CSF. J. Physiol., 307, 83P

28. Carey, M. E., Davson, H. and Bradbury, M. W. B. (1981). Effect of severe hypoglycaemia upon CSF formation. J. Neurosurg., 54, 370-379

29. Davson, H., Hollingworth, J. G., Carey, M. B. and Fenstermacher, J. D. (1982). Ventriculo-cisternal perfusion of 12 amino acids in the rabbit. J. Neurobiol., 13, 293-318

30. Davson, H., Begley, D. J., Chain, D. G., Briggs, F. D. and Shepland, M. T. (1986). The steady state distribution of cycloleucine and AIB between plasma and CSF. Exp. Neurol., 91, 163-173

31. Zlovokić, B. V., Segal, M. B., Begley, D. J., Davson, H. and Rakić, L. J. (1985). Permeability of the blood-CSF and blood-brain barrier to thyrotropin releasing hormones. Brain Res., 358, 191-199

32. McComb, J. G., Davson, H. and Hollingworth, J. R. (1985). Further studies in the difference between ventricular and subarachnoid perfusion. Brain Res., 89, 81-91

33. Zlovokić, B. V., Davson, H., Preston, J. and Segal M. B. (1987). The effects of aluminium chloride on rate of secretion of the cerebrospinal fluid. Exp. Neurol., 98, $436-452$ 


\title{
Recollections of Hugh Davson
}

\author{
William Oldendorf
}

\section{First Meeting}

I first met Hugh by accident. In the summer of $1964 \mathrm{I}$ happened into a lecture hall at UCLA in which there was a lecture in progress. A scholarly looking and sounding Englishman was speaking on cerebrospinal fluid. I had heard that Hugh was in the States setting up the eye institute in Louisville. That the lecturer was indeed Hugh was confirmed at the end of his talk, when the host faculty member thanked him for his lecture. I then walked to the front of the hall, approached Hugh, introduced myself (he hadn't the least notion of who I was) and briefly told him of my interest in BBB. He listened politely, and when I asked if he could visit my laboratory he suggested we go immediately since his time was short. We went to my small lab and, after showing him my attempts at measuring human BBB in vivo, I mentioned that I had thought of visiting him in London in the fall, when I planned to enquire whether I might spend a year in his laboratory, beginning in the summer of 1965 . To my astonishment, he offered me, on the spot, the opportunity of spending the proposed year with him. ('Why wait until the fall?') This was about two hours after I had wandered into his lecture and first laid eyes on him. With no formalities and no correspondence he signed me up. That year in his laboratory was a delight and completely redirected my research thinking.

\section{Academic Honesty}

Shortly after starting that year, the Royal Society of Medicine was presenting a one-day symposium on membrane permeability. Hugh was the first speaker and discussed the BBB. I attended and listened with interest but, of course, contributed nothing. About two years later the symposium appeared in print in the Society's proceedings. The first article was Hugh's material on BBB, but to my astonishment, I was second author. I rapidly scanned the article for a possible explanation. In two sentences Hugh speculated that the brain capillary was transformed into a 
BBB by a humoral influence generated by glial cells. This was my suggestion during a discussion with Hugh at least two years before this article was published. Hugh had thought the speculation had merit and took the opportunity of getting it conveniently published in this Royal Society of Medicine symposium. A lesser person might have done so with no acknowledgement of its origin. In this case his acknowledgement was provided by putting me on as second author. I have watched with interest the many publications during the past 10-15 years which support the early speculation about a glial humoral role in BBB formation.

\section{The Brain Uptake Index (BUI)}

In 1969 I developed the BBB permeability measurement determining the fraction of a carbon-labelled test substance taken up by rat brain during a single microcirculatory pass following a rapid carotid injection. Tritiated water was injected in the same solution as a diffusible internal standard, with decapitation of the rat 5 seconds after injection. Our initial results suggested that it could be quite useful, and I prepared them for publication. Uncertain of the theoretical soundness and originality of the idea, I first sent the material to Hugh for his comment. He replied 'I have discussed your idea with Keasley (Welch) and we believe it to be sound and possibly valuable. In addition, it shows what a year in my laboratory can do for someone'.

\section{The Devon Death March}

In April, 1970, on a Sunday, I was scheduled to visit Hugh at his cottage in Devon. My train arrived at Barnstaple station at noon. Hugh and Marjorie were waiting. Hugh tossed my suitcase in the back of their car, whereupon Marjorie drove off. I was perplexed by this, but Hugh explained that it was such a pleasant day he thought we would walk to the cottage. He was a little vague about how far it was to the cottage, but surely 'only a few miles'.

We began our walk at about noon and for two or three hours a lively discussion ensued, but as the miles passed, it became clear at about 5 p.m. that we were lost. We had been so engrossed in our conversation that we had walked down some wrong road. There was about a mile of railway track down which we had walked which Hugh didn't recognize. At about 7 p.m. it was turning dark and I was becoming concerned. Much of this concern was due to the nature of the one-lane, high-walled roads which allowed only an occasional glimpse of the surrounding landscape for orientation. Hugh was especially concerned because we had been on the 
road for about seven hours and, being Sunday, the few pubs we had passed were closed. Our problem was suddenly resolved by the appearance in our path of an automobile driven by another house-guest of Hugh's, dispatched by Marjorie to scour the local roads for us. Actually we were only about half a mile from the cottage when rescued. Hugh later dubbed our protracted walk The Devon Death March. 